\title{
CURRENT TRENDS IN THE USAGE OF THE DIGITAL VERSION OF THE LOCAL MASTER PLAN (eMPZP), AS ILLUSTRATED WITH THE EXAMPLE OF TOMICE MUNICIPALITY
}

\section{Karol Król}

\section{Summary}

The purpose of the present work was to analyse the current trends in the usage of a web-based application presenting the local spatial development plan for the Tomice municipality (the eMPZP master plan). Data collection began on January 1, 2013. The values of selected measures of the eMPZP usage were obtained with the aid of the Google Analytics application. Results obtained during the period of over 5 years have been analysed in the present study. The biggest interest in the local plans of Tomice municipality has been noted from two urban centres - the towns of Krakow and of Wadowice. It has been demonstrated that the current monitoring provides information about the usage statistics of the eMPZP application, but it does not provide information about what the users were actually looking for. Also, it fails to facilitate the identification of areas (municipalities, sections, plots of land), which were the most popular, that is those places whose designation in the local plan was checked most frequently.

\section{Keywords}

web analytics $\bullet$ user statistics $\bullet$ local (development) plan $\bullet$ monitoring

\section{Introduction}

Publishing any given website completes the stage of its implementation. The next stage should consist of actions aimed at its promotion and development, as well as monitoring. The latter, in turn, can provide data that shall ultimately influence management effectiveness - the management of the organization, the process, or the web service itself. All websites may be subjected to monitoring, regardless of the techniques that were employed in their development and the content that they present. This also applies to planning studies published on the Internet in the form of various map services [Król and Prus 2017].

That which can be measured is important, but not everything that is important can be measured, as Albert Einstein famously said. There is no management without 
measurement. Entities that understand the potential of web analytics are increasingly monitoring their websites and web applications, measuring complete paths, and taking into account various patterns of user behaviour [Chaffey and Patron 2012]. Mature analytical culture allows these entities to effectively use that data in their decisionmaking process, and it is irrelevant whether this concerns business issues or planning issues [Bluerank 2014]. The private sector uses web analytics much more frequently and to a more advanced degree compared to public administration agencies, including local self-government units. Specialists and skills in using such data are still insufficient in their number. At the same time, the importance of Internet research is growing, and the learning process of using such research is progressing. The purpose of the present work was to analyse trends in the use of the specific web application presenting the local spatial development plan for the Tomice commune. At the same time, research questions were raised: What information does the current monitoring of the application provide? And how can this information be used by the municipal authorities?

\section{Maps on the Internet - outline of the issues}

The development of information technology has enabled the introduction of advanced ways of cartographic visualization on the Internet, and the popularization of graphic forms of transmitting geographic information. Over the past few years, the share of spatial data that is available online (within Internet resources) has significantly increased. Due to the complexity of the cartographic image, the maps meet many different functions in the information exchange process. From the user's point of view, the most important function of the map is the visualization of phenomena in geographical space [Król and Gawroński 2018]. Digital maps increasingly often serve as a component of various applications and websites [Król and Prus 2016], although modern geo-information websites are mostly data-oriented systems - that is to say, maps are created at the user's request and according to his particular needs [Kowalski 2007]. Interactivity of online maps leads to the situation where the user ceases to be a passive observer, and instead, he participates in the development of a cartographic product - both by selecting data and the way they are visualized, and also by having the option of placing new data within the service [Gotlib 2008, Król 2016].

An interesting aspect of online cartography is the broad variety of ways in which maps can be disseminated [Peterson 2007]. Online maps take different forms, and they are characterized by wide availability, which is conducive to reaching a large and diverse group of recipients [Górski 2005]. They can be published in static (raster) or dynamic (vector) format. They most often take the form of website components, map services or geo-portals [Kukułka 2011]. Map components are multimedia-based, interactive thematic maps that fulfil a specific function, and provide a certain range of functionality, which is usually very narrow. They are typically part of a website or a web application [Król and Szomorova 2015]. Geo-information web services are public geographic information systems with functionalities depending on the destination, and with content tailored to their users' needs [Kowalski 2008]. Geo-portals are web appli- 
cations that provide their users with access to spatial data and to related services, such as display, analysis and editing. They constitute a point of contact with the users. Their structure may include subsystems, which are interrelated with one another [Wojsyk et al. 2009]. In addition, such applications facilitate the integration of data from any source [Kukułka 2011]. All this makes the online city plans and online spatial development plans, published in the form of independent mapping websites or website components, more and more common. They constitute an example of a popular means of disseminating geo-information, addressed to a wide audience via the Internet [Górski 2005]. They can be a tool for informing, educating and exerting information pressure [Król 2015].

Open access to local master plans and studies of conditions and directions of spatial development, along with the possibility of their spatial reference to the cadastral map and other layers important for determining the current status of land, may be of key importance in the decision-making process. Online map services are a response to the growing demand for information about local plans, their borders and basic attributes, reported both by the officials, as well as residents and investors [Brzuchowska 2003]. The monitoring of such websites can provide information on the level of interest in real estate in the given municipality, and also as to which areas are most attractive to investors. Furthermore, online geographic information systems (participatory public GIS) may be a tool used in public consultations (in the local planning process). Such portals can contribute to greater transparency and greater community participation in the planning process [Kaczmarek and Wójcicki 2015].

\section{Web analytics}

The analytics cover extensive use of data, statistical and quantitative analyses, explanatory and prognostic models, as well as evidence-based management - both when making decisions and taking action. They can be strategic for the organization, and they can be helpful in making decisions relevant to further development [Davenport and Harris 2010]. One of the types of analytics that has developed significantly over the last few years is web analytics.

New communication technologies have not only opened new modes in which the audience interacts with the news, but also created new ways in which organizations can monitor online audience behavior [Tandoc 2014]. The increasing ubiquity of Internet access and the frequency with which people interact with it raise the possibility of using the Web to better observe, understand, and monitor several aspects of human social behaviour [Gonçalves and Ramasco 2008]. Web analytics are an approach that can potentially meet organisational demand for effective evaluation of online strategies [Phippen et al. 2004]. Measuring website traffic and analysing user navigation are common procedures for any website provider. The monitored items vary from simple statistics to a complex and comprehensive analysis of the navigation behaviour of website visitors. This information can be used to fine-tune the measured website in order to provide visitors with more content that they are interested in, as well as 
to improve navigation. Whatever the fundamental motive may be, web analytics is a cornerstone to creating customer satisfaction among website visitors [Pakkala et al. 2012].

Web analytics includes the measurement, collection, analysis, visualization and reporting of Internet data in order to understand and optimize the effectiveness of websites and the processes occurring in their environment. It is the younger sister of a much older field - business analytics, which for many years now has served as a tool for supporting the development of various organizations [Robak 2017].

Effective web analytics would not be possible without specialized tools. One of the oldest among those is Webalizer, initiated in 1997 by Bradford L. Barrett [Robak 2017]. Analytical tools today provide the basis for monitoring websites and web applications. According to an Analyzeo study, $86.9 \%$ of e-commerce representatives use them. The unquestioned leader is Google Analytics, which is selected by as many as $82.2 \%$ of analysts [Analyzeo 2015].

Web analytics allows you to get to know and understand your website or web application. According to slightly more than $90 \%$ of all entities that use analytical tools, knowledge about how a user behaves on the pages of a given website can affect the increase in goal conversion. Users of tools providing information about website usage statistics most often analyse the number of visits and the average time that users spent browsing their website [Analyzeo 2015]. Despite this, many entities still do not use the full potential of web analytics. Studies have shown that this is most often due to the lack of time and/or the lack of ability to draw conclusions from the data thus obtained, as well as the degree of complexity of the analysis [Tworzydło et al. 2017].

There are two basic forms of web analytics - one, on-site (site-centric, where the website in at the centre of our focus) and the other, off-site. Site-centric monitoring responds to the question "how many/how much?" and it includes the measurement of website usage statistics, whereas off-site analytics include the measurement of external factors related to the website, such as the presence of the brand in social networking websites and the Internet as a whole [Ołdak 2010]. On-site analytics examine users' behaviour during their presence on the website, in order to answer questions such as how much interest is generated by the particular content, in what way users get to the content, and how they use it. The main goal of on-site analytics is to measure the effectiveness of the website by providing or isolating feedback information, thus making it possible to evaluate the effect of specific actions or particular expenditures made [Robak 2017].

\section{The eMPZP online application}

The website presenting the local spatial development plan for the Tomice municipality (in the Małopolska region of Poland) was created in 2012 on the basis of the jQuery JavaScript library, omitting extended geoinformation platforms, such as MapServer or GeoServer. The application was created so that the user, in addition to the map, could also obtain text information about the fact that a given plot in land records is intended 
for specific purposes in the local master plan. The application was developed on the basis of raster maps and coordinates of polygons, created after the transformation of vector maps using the QGIS component - HTML Image Map Plugin. Thus acquired, the structure was extended by adding the functionality of highlighting objects on the map, using the jQuery Maplight script (Fig. 1). The completed application was placed on the server, published on the municipal website, and then monitored (at website address: tomice.pl/mpzp, further: eMPZP). The main function of the application is to present the map, and to provide text information on the land uses of registered plots in the local plan for specific purposes [Salata and Król 2012].

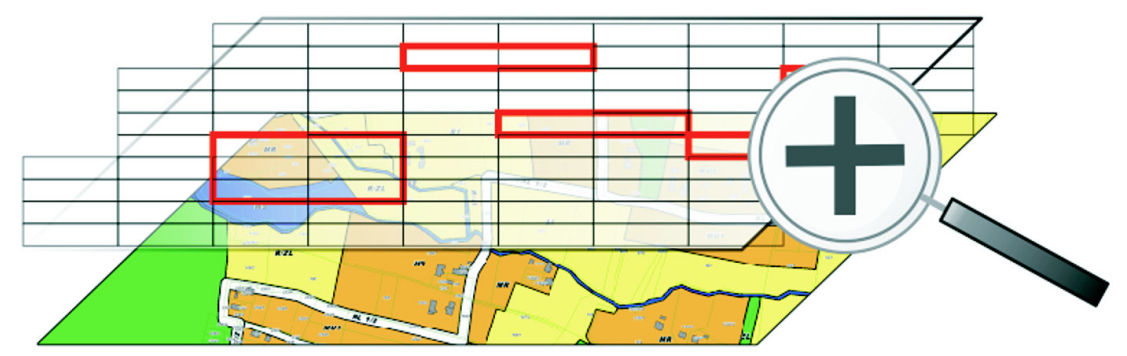

Source: developed by the author

Fig. 1. Scheme of the active area layer (HTML area tag) generated over the raster map using jQuery Maplight

\section{Material and methods}

The following were included among the basic measures of using the eMPZP application, among others: the number of impressions and the average time spent by the user on the website; sources of traffic; as well as the geolocation data of the users. These are "traditional" measures that provide a general view of the effectiveness of a website or web application [Palmer 2002]. The values of adopted measures were obtained using Google Analytics, one of the most popular tools for analysing statistics on the use of websites [Plaza 2011]. Data collection began on January 1, 2013. The results of measurements from the period of more than 5 years were analysed, that is, from the first day of statistics' launch to May 15, 2018. In addition, the analysis of interest in the eMPZP application (containing local plans) used selected external test applications, which are recognized and valued by analysts (Table 1).

Semstorm is a tool that allows you to analyse the visibility of your site in Google search results. SEMrush is a powerful and versatile competitive intelligence suite for online marketing, from SEO and PPC to social media and video advertising research. SimilarWeb allows you to estimate the size of selected site usage statistics based on Web Listening. 
Table 1. Tools used in the estimation of web traffic to the eMPZP website

\begin{tabular}{|c|c|c|}
\hline Testing tool & Type of application & Description \\
\hline Semstorm & Web application & Versatile marketing support tool in search engines \\
\hline SEMrush & Web application & $\begin{array}{c}\text { All-in-one Marketing Toolkit } \\
\text { for digital marketing professionals }\end{array}$ \\
\hline SimilarWeb & Browser Extension & Website Traffic Sources and Ranking \\
\hline
\end{tabular}

Source: developed by the author

\section{Measurement results}

In the period from January 1, 2013 to May 15, 2018, 9,977 unique users have visited the eMPZP application; they have initiated 15,271 sessions ${ }^{1}$, and generated 19,111 hits. The biggest interest in local plans of Tomice has been recorded as coming from such urban centres as Kraków (29\% of users) and Wadowice (24\% of users). The next largest groups of users came from the following cities: Warsaw, Katowice and Wrocław, in that order.

Repeated users constituted $20 \%$ of the registered users who had previously benefited from the eMPZP application. Traffic from referral sites accounted for $12 \%$ of all visits, whereas traffic from search results (organic search) made up around $31 \%$ of all visits (Fig. 2). What is puzzling is the "direct" traffic (direct entry to the website), which came from visits resulting from entering the application's address in the browser's address bar: "tomice.pl/mpzp/". The bounce rate in the specific studied period was $83.17 \%$, and the average duration of the session was just over a minute (00:01:10).

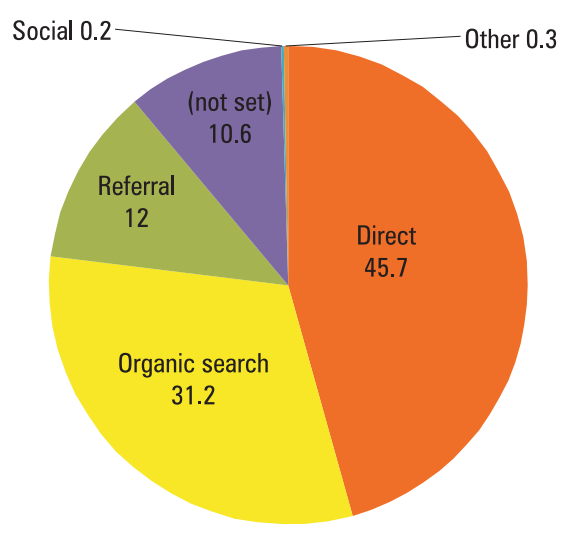

Source: Google Analytics

Fig. 2. Sources of user traffic to eMPZP

1 A session is the time (the duration) in which the user actively uses a given website or an application. 
Bounce rate is the percentage of sessions during which the user saw only one page of the website and did not interact with it (that is, he left the website). However, for websites that consist of one page only, or those comprising of specific types of content, which is most typically used in sessions limited to one page, a high bounce rate is not unusual. This is also how the eMPZP application was made. The home page that the user visits only serves as the gateway to the map of local master plan, which is elicited in the iframe window (the "floating frame").

In the period from January 1, 2013 to the end of 2016, an increased interest in Tomice's local plans was observed (expressed in eMPZP usage statistics). In 2017, there was a drop in the numbers of new users, which translated into fewer views (Fig. 3).

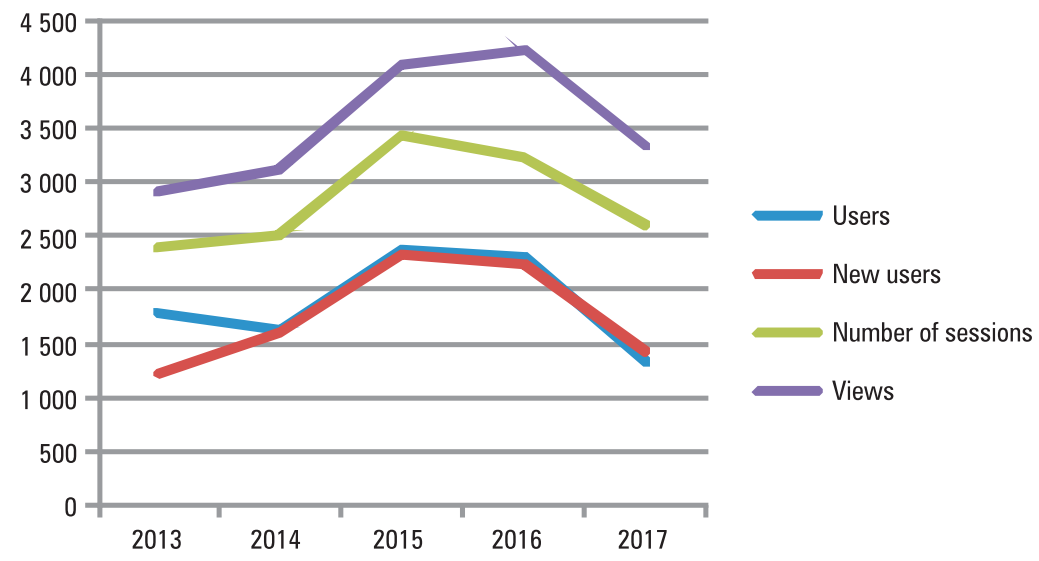

Source: developed by the author based on Google Analytics

Fig. 3. Selected user statistics for eMPZP application between 2013-2017

Comparing the usage statistics of the application leads us to observe an increase in the number of its users in the period from 1 January to 15 May 2018, compared to the same period in the previous year, that is, in 2017 (Table 2). This is the basis for forecasting the probable increased interest in the application (i.e. in the local plan) in the following years.

In its current form, viewing the eMPZP application on mobile devices poses much difficulty (it is not convenient) or may even be impossible. This fact results mainly from the application's architecture, which is based on a raster map, whereas the application itself is not responsive, which means that it does not adapt to the screen size of the device on which it is displayed. This is reflected in the usage statistics. Only 5\% of users of the application made an attempt to view it on mobile devices, with a slight increase in such activity (Table 3). 
Table 2. Comparison of user statistics of eMPZP usage in the period between 1 January and 15 May in the years 2017 and 2018

\begin{tabular}{|c|c|c|}
\hline Web statistics & $\begin{array}{c}\text { From 1 January 2017 } \\
\text { to 15 May 2017 }\end{array}$ & $\begin{array}{c}\text { From 1 January 2018 } \\
\text { to 15 May 2018 }\end{array}$ \\
\hline Users & 614 & 686 \\
\hline New users & 555 & 614 \\
\hline Number of sessions & 907 & 1108 \\
\hline $\begin{array}{c}\text { The average duration of the } \\
\text { session }\end{array}$ & $00: 00: 54$ & 1393 \\
\hline Views & 1168 & 82.13 \\
\hline Bounce rate (\%) & 81.7 & \\
\hline
\end{tabular}

Source: developed by the author based on Google Analytics

Table 3. Type of device used for accessing and browsing the eMPZP website

\begin{tabular}{|c|c|c|c|c|}
\hline \multirow{3}{*}{ Type of device } & \multicolumn{4}{|c|}{ Measurement period } \\
\hline & \multicolumn{2}{|c|}{$\begin{array}{c}1 \text { January } 2013 \\
\text { to } 31 \text { December } 2016\end{array}$} & \multicolumn{2}{|c|}{$\begin{array}{l}1 \text { January } 2013 \\
\text { to } 1 \text { May } 2018 .\end{array}$} \\
\hline & Number of users & $\%$ & Number of users & $\%$ \\
\hline $\begin{array}{l}\text { Desktop and } \\
\text { tablet }\end{array}$ & $7696(8076)$ & 95,29 & 9294 (9 967) & 93.25 \\
\hline Mobile & 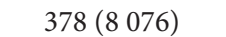 & 4.68 & 698 & 7 \\
\hline
\end{tabular}

Source: developed by the author based on Google Analytics

\section{Observations and inferences}

In 2017, decreased activity of users was recorded on eMPZP websites. However, this was not caused by the lack of interest in local plans during this period, but instead resulted from the modernization of the Tomice municipality's website. The existing website, where the link to the eMPZP was available, has been archived and replaced with a new one. In the new version of the website, the link to eMPZP was removed from a well-displayed position (it was moved down the page), which might have had a negative impact on the visibility of the application to the users. At the same time, however, the web address of the application remained on the top of the Google search results after the keywords "mpzp Tomice" have been entered.

The current eMPZP monitoring does not provide information as to whether the user has found the information he was looking for. At this point it is worth noting that the application itself has limited functionality and it does not provide a module for land plot search on the map (in the database). Currently, the search of the plot must 
be preceded by the selection of the area, and it consists in manually exploring the map (using browser sliders). Furthermore, monitoring also does not facilitate identifying areas (municipalities, precincts, land plots), which enjoyed the greatest interest, that is places for which land use was most often checked in the local plan. In addition, the menu is not monitored, which does not allow us to clearly determine, which features of the land plots in the master plan were the most popular. Such information can be obtained through the implementation of analytical tools that track users' activity and present it in the form of a heat map, where the intensity of colour reflects the intensity of use (i.e. amount of clicks). All this shows that the current monitoring provides information on the (quantitative) usage statistics of the eMPZP application, and on its users, but it does not provide information about what they were looking for, and which places in the municipality they were most interested in.

Current on-going monitoring is part of on-site analytics. In a situation where social networks, blogs and user forums play important role in the transmission of information, it is also recommended that application environment should be monitored (so-called "Web Listening"), which may help identify areas within the municipality that are most interesting to investors, as well as potential problem areas.

\section{Conclusions}

None of the external tools used to estimate website traffic provided information about eMPZP usage statistics. In each case, the lack of data was the result of insufficient range of eMPZP impact, which in itself is also a useful feedback. In its current edition, and with the current form of sharing and promotion of the application, it has only local coverage, and its impact is low. In addition, it does not appear in mentions posted in social media; and also there is a low number of links leading thereto from external sources (backlinks). All this confirms that the application is not being developed, and that the municipality is not promoting it.

Analysis of eMPZP usage statistics makes it possible to forecast a slight increase of interest in the application within the next 2-3 years, but at most up to the level from 2016 (before the decrease caused by the modernization of the municipal website). It is unlikely that the dynamics of eMPZP use will be any larger. The eMPZP application is not displayed in a prominent position in the website of the Tomice Municipal Office. Also, it is not promoted in any way. In a sense, this is due to the nature of the application, made using the technology, which is archaic today. The website's architecture prevents the implementation of new functionalities. Furthermore, the eMPZP service does not meet the technical requirements for geoinformation projects, as specified in the Act on spatial information infrastructure [Ustawa 2010]. Despite these limitations, research has shown that the application is still attracting the interest on the part of users. Therefore, removing it from the municipal website would not be justified; at least not until it is replaced by a geoportal. 


\section{References}

Analyzeo 2015. Analityka internetowa - przyszłość rynku e-commerce. Raport, https://goo.gl/ zhJegK (accessed: 14.05.2018).

Bluerank 2014. Analityka internetowa w Polsce. Trendy i prognozy na najbliższe miesiące wybrane przez ekspertów Bluerank, https://goo.gl/RGQQJ7 (accessed: 14.05.2018).

Brzuchowska J. 2003. System informacji przestrzennej dla planów zagospodarowania przestrzennego: potrzeby i kierunki rozwoju. Roczniki Geomatyki - Annals of Geomatics, 1(1), 81-87.

Chaffey D., Patron M. 2012. From web analytics to digital marketing optimization: Increasing the commercial value of digital analytics. Journal of Direct, Data and Digital Marketing Practice, 14(1), 30-45.

Davenport T.H., Harris J.G. 2010. Inteligencja analityczna w biznesie. Nowa nauka zwyciężania. Wyd. MT Biznes, Warszawa.

Gonçalves B., Ramasco J.J. 2008. Human dynamics revealed through Web analytics. Phys. Rev. E, 78(2), 026123.

Gotlib D. 2008. Nowe oblicza kartografii - Internet a kartografia. Polski Przegląd Kartograficzny, 40, 237-246.

Górski J. 2005. Przemiany internetowych planów miast polskich. Roczniki Geomatyki - Annals of Geomatics, 3(2), 61-68.

Kaczmarek T., Wójcicki M. 2015. Uspołecznienie procesu planowania przestrzennego na przykładzie miasta Poznania. Ruch Prawniczy, Ekonomiczny i Socjologiczny, 77(1), 219-236.

Kowalski P.J. 2007. Znaczenie integracji danych geograficznych w serwisach internetowych typu „mashup”. Archiwum Fotogrametrii, Kartografii i Teledetekcji, 17a, 395-404.

Kowalski P.J. 2008. Techniczne aspekty redagowania i użytkowania serwisów geoinformacyjnych. Polski Przegląd Kartograficzny, 40, 337-348.

Król K. 2015. Conception of a touristic map and nature protection forms created with use of open data sources and free software on a Grybów commune example. Geomat. Landmanag. Landsc. (GLL), 4, 49-59.

Król K. 2016. Data presentation on the map in Google Charts and jQuery JavaScript technologies. Geomat. Landmanag. Landsc. (GLL), 2, 91-106.

Król K., Gawroński K. 2018. Informational, Educational, and Scientific Values of Environmental Data Interactive Visualizations. Geomatics and Environmental Engineering, 12(2), $51-62$.

Król K., Prus B. 2016. The comparative analysis of selected interactive data presentation techniques on the example of the land use structure in the commune of Tomice. Polish Cartographical Review, 48(3), 115-127.

Król K., Prus B. 2017. Monitoring the use of the internet application for Tomice municipality local plan of spatial development. Geomat. Landmanag. Landsc. (GLL), 2, 91-98.

Król K., Szomorova L. 2015. The possibilities of using chosen jQuery JavaScript components in creating interactive maps. Geomat. Landmanag. Landsc. (GLL), 2, 45-54.

Kukułka M. 2011. Nowe aspekty metodyczne projektowania serwisów map internetowych. Polski Przegląd Kartograficzny, 43(3), 239-251.

Ołdak A.K. 2010. Web Analytics. Polska Agencja Rozwoju Przedsiębiorczości (PARP), Warszawa.

Pakkala H., Presser K., Christensen T. 2012. Using Google Analytics to measure visitor statistics: The case of food composition websites. International Journal of Information Management, 32(6), 504-512. 
Palmer J.W. 2002. Web Site Usability, Design, and Performance Metrics. Information Systems Research, 13(2), 151-167.

Peterson M.P. 2007. Mapy i Internet: pogłębianie się kontrastów w rozwoju. Polski Przegląd Kartograficzny, 39(4), 333-339.

Phippen A., Sheppard L., Furnell S. 2004. A practical evaluation of Web analytics. Internet Research, 14(4), 284-293.

Plaza B. 2011. Google Analytics for measuring website performance. Tourism Management, $32(3), 477-481$.

Robak M. 2017. Analityka internetowa i jej potencjał w trzecim sektorze. Kultura - Media Teologia, 30, 52-69.

Salata T., Król K. 2012. Zastosowanie języków skryptowych JavaScript w przetwarzaniu i wizualizacji danych przestrzennych na przykładzie planu miejscowego gminy Tomice. [In:] Badania regionalnych i lokalnych struktur funkcjonalno-przestrzennych, D. Ilnicki, K. Janc (eds.). Rozpr. Nauk. Inst. Geogr. Rozw. Region., 29. Uniwersytet Wrocławski, Wrocław, 247255.

Tandoc E.C. jr. 2014. Journalism is twerking? How web analytics is changing the process of gatekeeping. New Media \& Society, 16(4), 559-575.

Tworzydło D., Tobiasz M., Szymański W. 2017. Znaczenie narzędzi analitycznych w skutecznym zarządzaniu sklepem internetowym i stopień ich wykorzystania przez właścicieli e-sklepów. Zeszyty Naukowe Wyższej Szkoły Humanitas. Zarządzanie, 4, 79-93.

Ustawa z dnia 4 marca 2010 r. o infrastrukturze informacji przestrzennej (tekst jedn. Dz. U. z 2017 r., poz. 1382 z późn. zm.).

Wojsyk K., Bajorski M., Bednarski M. 2009. Geoportale miejskie i turystyczne na przykładzie Częstochowy. Roczniki Geomatyki - Annals of Geomatics, 7(6), 113-120.

\author{
Dr inż. Karol Król \\ Uniwersytet Rolniczy w Krakowie \\ Katedra Gospodarki Przestrzennej i Architektury Krajobrazu \\ 30-059 Kraków, al. Mickiewicza 24/28 \\ e-mail:k.krol@onet.com.pl
}

